\title{
Variabel-Variabel yang Memengaruhi Status Stres Pekerja Komuter dengan Kendaraan Bermotor Pribadi dan Umum di Jabodetabek
} Analisis Data Survei Komuter Jabodetabek Tahun 2019

\author{
(Variables that Affect the Stress Status of Commuter Workers with Private and Public Motorized \\ Vehicles in Jabodetabek: Analysis of 2019 Jabodetabek Commuter Survey Data)
}

\author{
Desy Natalia Sasongko ${ }^{1 *}$, Yaya Setiadi² \\ ${ }^{1,2}$ Politeknik Statistika STIS \\ Jalan Otto Iskandardinata No.64C, RT 001/ RW 004, Bidara Cina, Jatinegara, Jakarta Timur \\ E-mail: 211709616@stis.ac.id
}

\begin{abstract}
ABSTRAK
Komuter adalah seseorang yang bekerja/sekolah/kursus di luar kabupaten/kota tempat tinggalnya yang pergi dan pulang pada hari yang sama. Sebagian besar kegiatan utama komuter adalah bekerja. Pekerja komuter baik yang menggunakan kendaraan bermotor pribadi maupun umum tentunya mengalami stres berkomuter. Stres tidak bisa disepelekan, karena dapat memengaruhi kesehatan dan kinerja pekerja. Oleh karena itu, penelitian ini bertujuan untuk mengetahui variabelvariabel yang berpengaruh signifikan terhadap status stres pekerja komuter di Jabodetabek berdasarkan kendaraan yang digunakan. Data yang digunakan berasal dari Survei Komuter Jabodetabek tahun 2019. Adapun metode analisis inferensia yang digunakan adalah analisis regresi logistik biner. Hasil menunjukkan bahwa variabel yang berpengaruh signifikan terhadap status stres pekerja komuter yang menggunakan kendaraan pribadi adalah status perkawinan, durasi perjalanan, dan kemacetan. Sedangkan pada pekerja komuter dengan kendaraan bermotor umum yang berpengaruh signifikan adalah umur, durasi perjalanan, dan kemacetan.
\end{abstract}

Kata kunci: stres, pekerja komuter, kendaraan bermotor pribadi, kendaraan bermotor umum, regresi logistik biner

\begin{abstract}
Commuter is someone who works/schools/courses in the outside of the regency/city where he/she lives who goes and returns on the same day. Most of the commuters are working. Commuter workers both using private or public motorized vehicle certainly experience commuting stress. Stress cannot be underestimated because it can affect workers' health and performance. Therefore, this study aims to determine the variables that significantly affect the stress status of commuter workers in Jabodetabek based on the vehicle used. The data used is the 2019 Jabodetabek Commuter Survey. The inferential analysis method used is binary logistic regression analysis. The result shows that marital status, duration of trips, and traffic jam have a significant effect on the stress status of commuter workers who use private motorized vehicles. Meanwhile, for the commuter workers with public motorized vehicle are age, duration of trips, and traffic jam.
\end{abstract}

Keywords: stress, commuter workers, private motorized vehicle, public private vehicle, binary logistic regression

\section{PENDAHULUAN}

Perbedaan potensi dan kemampuan antara wilayah satu dengan yang lain mendorong penduduk untuk melakukan mobilitas. Seiring berjalannya waktu, pola mobilitas penduduk mengalami pergeseran dari permanen berubah menjadi nonpermanen. Badan Pusat Statistik (BPS) (2019) mengatakan bahwa perubahan pola mobilitas tersebut dikarenakan kemudahan akses transportasi dan kepemilikan kendaraan bermotor. Salah satu bentuk mobilitas nonpermanen yang sekarang semakin diminati oleh penduduk di kota-kota besar adalah komuter.

Jabodetabek (Jakarta, Bogor, Depok, Tangerang, dan Bekasi) merupakan salah satu wilayah di mana komuter berkembang dengan pesat. Tingginya biaya kebutuhan hidup di Jakarta menyebabkan sebagian penduduknya memilih bertempat tinggal di pinggiran Jakarta (Bodetabek). Walaupun demikian, sebagian dari mereka tetap menggantungkan kehidupan ekonominya pada wilayah Jakarta. Hal inilah yang menyebabkan Jakarta memiliki persentase pekerja mover komuter tertinggi dibanding provinsi lain pada tahun 2018 yakni sebesar 21,90 persen (BPS, 2019). Selain itu, hasil Survei Komuter Jabodetabek tahun 2019 menunjukkan bahwa sekitar 11 persen penduduk Jabodetabek adalah penduduk komuter.

Sayangnya, mobilisasi yang tinggi di Jabodetabek belum diiringi dengan pelayanan kendaraan umum yang memadai sehingga pola transportasi komuter masih bertumpu pada kendaraan pribadi (Riyadi dan 
Yudhistira, 2020). Sebagian besar pekerja komuter (73,69 persen) di Jabodetabek lebih memilih menggunakan kendaraan bermotor pribadi dibandingkan kendaraan bermotor umum (25,20 persen) sebagai moda transportasi utamanya. Besarnya volume kendaraan bermotor pribadi yang tidak diimbangi dengan ketersediaan jalan yang memadai dapat menimbulkan kemacetan parah terutama pada jam-jam puncak. Kemacetan yang dirasakan selama perjalanan tersebut dapat memicu terjadinya stres pada komuter (Morris dan Hirsch, 2015). Setidaknya ada sekitar 35,22 persen pelaku komuter di Jabodetabek yang mengalami stres akibat perjalanan dan sekitar 86 persen di antaranya adalah pekerja. Angka tersebut lebih tinggi dibandingkan Mebidang yang hanya sebesar 15,83 persen.

Stres tentunya dirasakan oleh pekerja komuter baik yang menggunakan kendaraan bermotor pribadi maupun umum. Penelitian yang dilakukan oleh Tajalli dan Hajbabaie (2017) menunjukkan bahwa kesehatan mental pekerja komuter di New York berbeda antar moda transportasi yang digunakan (mobil pribadi, bus kota, kereta bawah tanah, berjalan kaki, dan bekerja dari rumah). Lebih spesifik, O'Regan dan Buckley (2003) mengatakan bahwa pekerja komuter pengguna The Dublin Area Rapid Transit (DART) memiliki tingkat stres yang paling tinggi dibanding pekerja komuter pengguna mobil pribadi, bus, dan pejalan kaki. Hal tersebut sejalan dengan hasil penelitian Anable dan Gatersleben (2005) yang menemukan bahwa pekerja komuter di salah satu universitas di Inggris menilai positif perjalanan dengan mobil pribadi. Sebaliknya perjalanan dengan kendaraan umum dinilai paling negatif. Kendaraan umum memiliki skor yang rendah terkait aspek kenyamanan, rasa tidak stres, kontrol, dan kebebasan.

Penelitian sebelumnya seperti yang dilakukan oleh Legrain, Eluru, dan El-Geneidy (2015) di Kanada menemukan bahwa terdapat perbedaan variabel yang memengaruhi stres komuter antar kendaraan. Umur dan penghasilan berpengaruh signifikan pada pejalan kaki sedangkan pada pengguna kendaraan umum hanya penghasilan saja yang memiliki pengaruh signifikan. Selain itu, jenis kelamin dan durasi perjalanan berpengaruh signifikan baik pada pengguna mobil pribadi, kendaraan umum, dan pejalan kaki. Mao, Ettema, dan Dijst (2016) menunjukkan bahwa fleksibilitas dan kemacetan berpengaruh signifikan terhadap kepuasan perjalanan dengan bus dan mobil pribadi di Beijing. Kemudian, umur hanya berpengaruh signifikan negatif pada moda kereta bawah tanah.

Stres tidak bisa disepelekan karena berhubungan dengan buruknya kualitas tidur, kelelahan, depresi, dan merasa kurang sehat. Selain itu, stres juga berkorelasi negatif dengan kemampuan konsentrasi seseorang dalam menyelesaikan tugasnya. Pekerja komuter yang mengalami stres akan memiliki kinerja yang tidak optimal dan dapat merugikan perusahaan tempatnya bekerja. Oleh karenanya, penelitian terkait stres pekerja komuter perlu dilakukan. Ditambah lagi masih sedikit penelitian yang mengangkat permasalahan tentang stres pekerja komuter yang dihubungkan dengan jenis kendaraan di Indonesia. Adapun tujuan dari penelitian ini adalah mengetahui gambaran umum karakteristik pekerja komuter antara yang menggunakan kendaraan bermotor pribadi dan umum, mengetahui perbedaan proporsi pekerja komuter yang mengalami stres pada dua jenis kendaraan tersebut, mengetahui variabel apa saja yang berpengaruh signifikan terhadap stres pekerja komuter, dan mengetahui kecenderungan variabel yang berpengaruh signifikan terhadap status stres pekerja komuter baik pengguna kendaraan bermotor pribadi maupun bermotor umum.

\section{METODE}

\section{Landasan Teori}

Komuter adalah seseorang yang melakukan suatu kegiatan bekerja/sekolah/kursus di luar kabupaten/kota dan secara rutin pergi dan pulang pada hari yang sama (BPS, 2019). Sedangkan bekerja adalah kegiatan melakukan pekerjaan dengan maksud memperoleh atau membantu memperoleh penghasilan atau keuntungan, paling sedikit selama satu jam berturut-turut dan tidak terputus dalam seminggu terakhir (BPS, 2019). Dengan demikian pekerja komuter dapat diartikan sebagai seseorang yang melakukan pekerjaan untuk memperoleh penghasilan atau keuntungan di luar kabupaten/kota tempat tinggalnya dan secara rutin pergi dan pulang pada hari yang sama.

Perjalanan yang dilakukan secara rutin oleh pekerja komuter tidak selalu sesuai dengan harapan sehingga berdampak pada timbulnya stres. Kemudian kondisi di dalam kendaraan yang berbeda juga dapat berpengaruh terhadap stres selama perjalanan. Kendaraan secara garis besar dibagi menjadi kendaraan pribadi dan umum. BPS (2019) menyebutkan bahwa kendaraan pribadi adalah jenis transportasi yang hanya bisa digunakan sendiri, baik kendaraan bermotor maupun tidak bermotor. Lalu yang dimaksud dengan kendaraan umum adalah jenis transportasi yang penggunaanya tidak terbatas pada orang tertentu tetapi bisa digunakan oleh semua orang. Orang yang menggunakan transportasi ini biasanya membayar sebagai balas jasa. 
Terdapat beberapa variabel yang berpengaruh terhadap stres perjalanan yang dialami oleh pekerja komuter. Haider, Kerr, dan Badami (2013) menemukan bahwa umur, penghasilan, durasi perjalanan, dan kemacetan berpengaruh signifikan terhadap stres pekerja komuter. Penelitian lain yang dilakukan oleh Rosida, Sari, dan Irjayanti (2019) mendapatkan hasil bahwa jenis kelamin, durasi perjalanan, dan moda transportasi memiliki pengaruh yang signifikan terhadap stres perjalanan pekerja komuter. Selain variabel-variabel tersebut, masih ada variabel lain yang ditemukan berpengaruh signifikan terhadap stres pekerja komuter seperti status perkawinan (Demiral, 2018) dan jarak tempuh perjalanan (Koslowsky, Kluger, dan Reich, 1995). Oleh sebab itu, pada penelitian ini variabel yang diduga memiliki pengaruh signifikan terhadap status stres pekerja komuter adalah umur, jenis kelamin, status perkawinan, rata-rata penghasilan per bulan, durasi perjalanan, jarak tempuh perjalanan, dan kemacetan.

\section{Cakupan Penelitian}

Penelitian ini mencakup 13 kabupaten/kota yang tersebar di wilayah Jabodetabek, yakni Kota Jakarta Pusat, Kota Jakarta Barat, Kota Jakarta Selatan, Kota Jakarta Timur, Kota Jakarta Utara, Kabupaten Bogor, Kota Bogor, Kota Depok, Kabupaten Tangerang, Kota Tangerang, Kota Tangerang Selatan, Kabupaten Bekasi, dan Kota Bekasi. Adapun unit analisis penelitian adalah individu anggota rumah tangga yang berstatus komuter di Jabodetabek tahun 2019 dengan kegiatan utamanya adalah bekerja dan menggunakan moda transportasi yang sama untuk pulang/pergi dari tempat kegiatan. Data yang digunakan adalah data sekunder yang berasal dari hasil Survei Komuter Jabodetabek tahun 2019 yang dilaksanakan oleh BPS. Total sampel dari survei tersebut adalah sebanyak 12.960 rumah tangga. Kemudian agar didapatkan sampel yang sesuai dengan tujuan serta unit analisis penelitian ini, maka dilakukan seleksi data. Didapatkan 2.728 pekerja komuter dengan kendaraan bermotor pribadi dan 864 pekerja komuter dengan kendaraan bermotor umum.

Cakupan kendaraan bermotor pribadi meliputi sepeda motor pribadi/dinas dan mobil pribadi/dinas. Sedangkan kendaraan bermotor umum mencakup sepeda motor ojek/ojek online, mobil sewaan online, kendaraan jemputan, kendaraan omprengan/sharing, taksi, angkutan kota, bus umum, kereta, dan bus TransJakarta. Variabel yang digunakan dibedakan menjadi dua yakni variabel terikat dan variabel bebas. Variabel terikat dalam penelitian ini adalah status stres pekerja komuter dengan kendaraan bermotor pribadi dan status stres pekerja komuter dengan kendaraan bermotor umum. Status stresnya sendiri ada dua kategori yakni stres dan tidak stres. Kategori status stres tersebut didapatkan langsung dari jawaban responden di kuesioner Survei Komuter Jabodetabek 2019. Adapun variabel bebas yang digunakan meliputi umur, jenis kelamin, status perkawinan, rata-rata penghasilan per bulan, durasi perjalanan, jarak tempuh perjalanan, dan kemacetan.

\section{Metode Analisis}

Metode analisis penelitian ini adalah analisis deskriptif dan analisis inferensia. Analisis deskriptif digunakan untuk mengetahui gambaran umum karakteristik pekerja komuter antara yang menggunakan kendaraan bermotor pribadi dan kendaraan bermotor umum di Jabodetabek. Sedangkan analisis inferensia dalam penelitian ini menggunakan analisis regresi logistik biner yang sebelumnya didahului dengan uji proporsi dua populasi.

\section{Uji Proporsi Dua Populasi}

Uji ini dilakukan untuk mengetahui perbedaan proporsi pekerja komuter yang mengalami stres antara yang menggunakan kendaran bermotor pribadi dan yang menggunakan kendaraan bermotor umum. Hasil dari uji ini menentukan banyaknya model regresi logistik biner yang akan dibentuk. Apabila $\mathrm{H}_{0}$ ditolak maka disusun dua model regresi logistik biner (pekerja komuter dengan kendaraan bermotor pribadi dan pekerja komuter dengan kendaraan bermotor umum), sehingga bisa diketahui variabel apa saja yang masing-masing berpengaruh terhadap stres pekerja komuter. Namun, jika keputusannya adalah gagal tolak $\mathrm{H}_{0}$ maka cukup dibentuk satu model saja.Adapun hipotesis yang diuji adalah sebagai berikut:

$\mathrm{H}_{0}: \mathrm{p}_{1}=\mathrm{p}_{2}$ (Proporsi pekerja komuter dengan kendaraan bermotor pribadi yang mengalami stres akibat perjalanan sama dengan proporsi pekerja komuter dengan kendaraan bermotor umum)

$\mathrm{H}_{1}: \mathrm{p}_{1}<\mathrm{p}_{2}$ (Proporsi pekerja komuter dengan kendaraan bermotor pribadi yang mengalami stres akibat perjalanan lebih kecil dibandingkan proporsi pekerja komuter dengan kendaraan umum)

Statistik uji yang digunakan dapat didekati dengan distribusi normal baku (z):

$$
z=\frac{\hat{p}_{1}-\hat{p}_{2}}{\sqrt{\hat{p} \hat{q}\left(1 / n_{1}+1 / n_{2}\right)}}
$$

dimana: 
$\hat{p}_{1}=$ proporsi sukses pada sampel 1

$\hat{p}_{2}=$ proporsi sukses pada sampel 2

$\hat{p}=$ proporsi sukses gabungan

$\hat{q}=$ proporsi gagal gabungan

$\mathrm{n}_{1}=$ banyaknya sampel 1

$\mathrm{n}_{2}=$ banyaknya sampel 2

$\mathrm{H}_{0}$ ditolak apabila $z<-z_{\alpha}$ atau $p-$ value $<\alpha$ (Walpole et al., 2011).

\section{Regresi Logistik Biner}

Regresi logistik biner merupakan salah satu bentuk model regresi logistik, di mana variabel terikat dalam regresi logistik ini berupa data biner/dikotomi, sedangkan variabel bebasnya berupa data interval atau kategorik (Hosmer dan Lemeshow, 2013). Adapun bentuk model regresi logistik biner yang telah ditransformasi logit adalah sebagai berikut:

$$
g(x)=\ln \left(\frac{\pi(x)}{1-\pi(x)}\right)=\beta_{0}+\beta_{1} x_{1}+\cdots+\beta_{p} x_{p}
$$

dimana:

$\pi(x)=$ peluang kejadian "sukses" atau ketika $\mathrm{Y}=1$

$p \quad=$ jumlah variabel bebas

$\beta_{j}=$ nilai parameter dari variabel bebas ke-j, $\mathrm{j}=0,1, \ldots, \mathrm{p}$

Adapun pengujian yang dilakukan dalam regresi logistik biner meliputi:

- Uji Simultan

Pengujian simultan ini bertujuan untuk melihat pengaruh variabel bebas secara bersama terhadap variabel terikat.

- Uji Parsial

Uji parsial digunakan untuk mengetahui variabel bebas mana yang berpengaruh terhadap variabel terikat.

- Uji Kesesuaian Model

Pengujian ini bertujuan untuk melihat kesesuaian model yang telah dibangun secara simultan.

Kemudian, dalam pembentukkan model regresi logistik biner digunakan metode reduksi variabel bebas yakni backward stepwise. Alasan untuk mengurangi jumlah variabel bebas adalah agar model memiliki nilai standard error yang kecil dan cenderung lebih stabil.

\section{HASIL DAN PEMBAHASAN}

\section{Gambaran Umum Karakteristik Pekerja Komuter dengan Kendaraan Bermotor Pribadi dan Umum di Jabodetabek}

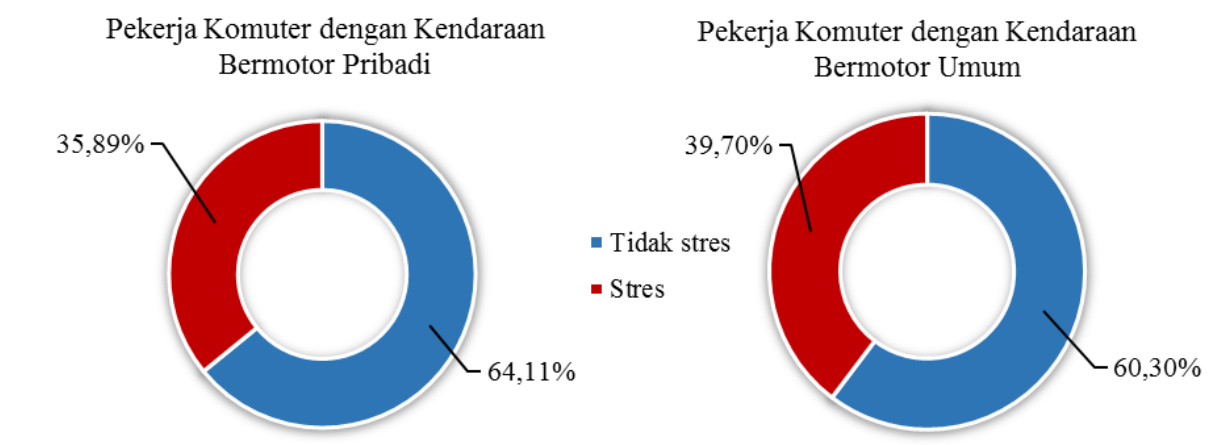

Sumber: Survei Komuter Jabodetabek 2019 (diolah)

Gambar 1. Persentase pekerja komuter dengan kendaraan bermotor pribadi dan umum di Jabodetabek 2019 berdasarkan status stres.

Gambar 1 menunjukkan bahwa persentase pekerja komuter dengan kendaraan bermotor umum yang mengalami stres perjalanan lebih banyak dibandingkan persentase pekerja komuter dengan kendaraan bermotor pribadi. Ada sekitar 39,70 persen pekerja komuter pengguna kendaraan bermotor umum yang mengalami stres perjalanan. Sedangkan untuk pekerja komuter yang menggunakan kendaraan bermotor pribadi hanya sebesar 35,89 persen. 
Tabel 1 menunjukkan bahwa pada pekerja komuter dengan kendaraan bermotor pribadi, persentase yang mengalami stres perjalanan terbesar berasal dari pekerja kelompok umur tua yang mana persentase tersebut sebesar 38,00 persen. Lain halnya dengan pekerja komuter yang menggunakan kendaraan bermotor umum di mana persentase terbesar yang mengalami stres terjadi pada pekerja kelompok umur menengah yakni sebesar 44,32 persen. Kemudian persentase pekerja komuter laki-laki yang mengalami stres perjalanan lebih besar pada pengguna kendaraan bermotor pribadi sedangkan pada pengguna kendaraan bermotor umum persentase antara laki-laki dan perempuan yang stres tidak jauh berbeda. Ada sebanyak 37,73 persen pekerja komuter dengan kendaraan bermotor pribadi berstatus kawin yang stres dan ada sebesar 31, 53 persen pekerja komuter berstatus tidak kawin yang stres. Angka tersebut lebih kecil dibanding persentase pekerja komuter berstatus kawin dengan kendaraan bermotor umum yang stres yaitu sebesar 41,15 persen. Sedangkan pekerja komuter yang tidak kawin dan mengalami stres sebanyak 37,97 persen.

Tabel 1. Gambaran umum karakteristik pekerja komuter dengan kendaraan bermotor pribadi dan umum di Jabodetabek tahun 2019 berdasarkan variabel bebas dan status stres.

\begin{tabular}{cccccc}
\hline \multirow{2}{*}{ Variabel } & Kategori & \multicolumn{2}{c}{ Pekerja Komuter dengan } & \multicolumn{2}{c}{ Pekerja Komuter dengan } \\
& & Kendaraan Bermotor Pribadi (\%) & Kendaraan Bermotor Umum (\%) \\
\cline { 3 - 6 } & Tua & 38,00 & 62,00 & 31,01 & 68,99 \\
\hline \multirow{2}{*}{ Umur } & Menengah & 37,88 & 62,12 & 44,32 & 55,68 \\
& Muda & 31,52 & 68,48 & 38,69 & 61,31 \\
Jenis kelamin & Laki-laki & 36,26 & 63,74 & 39,78 & 60,22 \\
& Perempuan & 34,30 & 65,70 & 39,63 & 60,37 \\
Status perkawinan & Kawin & 37,73 & 62,27 & 41,15 & 58,85 \\
Rata-rata & Tidak kawin & 31,53 & 68,47 & 37,97 & 62,03 \\
penghasilan per & Tinggi & 41,86 & 58,14 & 40,82 & 59,18 \\
bulan & Menengah & 37,08 & 62,92 & 42,82 & 57,18 \\
& Rendah & 32,13 & 67,87 & 35,78 & 64,22 \\
Durasi perjalanan & $\leq 30$ menit & 26,82 & 73,18 & 27,27 & 72,73 \\
& $31-60$ menit & 36,56 & 63,44 & 40,12 & 59,88 \\
Jarak tempuh & $>60$ menit & 48,82 & 51,18 & 45,33 & 54,67 \\
perjalanan & $\leq 30$ km & 34,59 & 65,41 & 37,46 & 62,54 \\
& $>30$ km & 44,09 & 55,91 & 45,20 & 54,80 \\
Kemacetan & Tidak mengalami & 10,23 & 89,77 & 27,16 & 72,84 \\
& kemacetan & & & & Tidak Stres \\
& Mengalami kemacetan & 43,99 & 56,01 & 47,22 & 52,78 \\
\hline
\end{tabular}

Sumber: Survei Komuter Jabodetabek 2019 (diolah).

Persentase pekerja komuter dengan kendaraan bermotor pribadi yang mengalami stres semakin bertambah seiring meningkatnya penghasilan, di mana persentase pekerja komuter berpenghasilan tinggi yang stres mencapai 41,86 persen. Berbeda dengan pekerja komuter pengguna kendaraan bermotor umum yang mana persentase pekerja dengan penghasilan menengah lah yang paling banyak mengalami stres yakni sebesar 42,82 persen. Persentase pekerja komuter pengguna kendaraan bermotor pribadi yang stres dengan durasi perjalanan > 60 menit adalah 48,82 persen. Angka tersebut lebih besar dibandingkan persentase pekerja komuter pengguna kendaraan bermotor umum yang hanya sekitar 45,33 persen. Berbeda dengan persentase pekerja komuter pada kategori durasi $\leq 30$ menit dan antara 31-60 menit, di mana pengguna kendaraan bermotor umum lebih banyak yang stres dibandingkan pengguna kendaraan bermotor pribadi. Selanjutnya, pekerja komuter yang melakukan perjalanan $>30 \mathrm{~km}$ memiliki persentase mengalami stres lebih tinggi dibanding yang $\leq 30 \mathrm{~km}$ baik pengguna kendaraan bermotor pribadi maupun umum. Hal yang sama juga berlaku bagi pekerja komuter yang mengalami kemacetan, ada 43,99 persen pekerja komuter stres dengan kendaraan bermotor pribadi dan ada 47,22 persen pekerja komuter stres dengan kendaraan bermotor umum. 


\section{Perbedaan Proporsi Status Stres antara Pekerja Komuter dengan Kendaraan Bermotor Pribadi dan Umum di Jabodetabek}

Perbedaan kondisi dan suasana antara kendaraan bermotor pribadi dan umum membuat adanya kemungkinan perbedaan stres yang dialami pekerja komuter. Oleh karena itu, sebelum membentuk model regresi logistik biner maka dilakukan uji proporsi dua populasi untuk mengetahui apakah memang terdapat perbedaan yang signifikan antara status stres pekerja komuter dengan kendaraan bermotor pribadi dan umum. Nilai statistik uji yang didapatkan sebesar -2,0184. Sehingga keputusan yang dihasilkan adalah tolak $\mathrm{H}_{0}$ dan dapat disimpulkan bahwa proporsi pekerja komuter dengan kendaraan bermotor pribadi yang mengalami stres lebih kecil dibandingkan proporsi pekerja komuter dengan kendaraan bermotor umum. Hal ini sejalan dengan penelitian Demiral (2018) yang menemukan bahwa pekerja komuter Turki yang menggunakan kendaraan umum lebih merasa stres dibanding yang menggunakan kendaraan pribadi. O'Regan dan Buckley (2003) juga menyebutkan bahwa pekerja komuter di Dublin yang menggunakan DART memiliki tingkat stres yang paling tinggi dibandingkan yang menggunakan mobil pribadi, bus, dan pejalan kaki. Hal tersebut merupakan akibat dari kondisi ramai dalam layanan DART.

Kecepatan, kenyamanan, dan kepraktisan menjadi alasan utama pekerja komuter memilih jenis kendaraan yang digunakan (BPS, 2019). Kendaraan pribadi seperti sepeda motor dan mobil pribadi dinilai lebih bisa memenuhi alasan-alasan tersebut (Aminah, 2016). Sugianti dan Anggorodi (2013) mengatakan bahwa pekerja komuter yang menggunakan kendaraan bermotor umum seperti TransJakarta sangat rentan terkena stres akibat lingkungan berupa kemacetan dan kondisi kendaraan bermotor umum yang buruk.

\section{Variabel-Variabel yang Memengaruhi Status Stres Pekerja Komuter dengan Kendaraan Bermotor Pribadi dan Umum di Jabodetabek}

Pembentukan model regresi logistik biner menggunakan metode Backward Stepwise (Wald) dengan tingkat signifikansi $(\alpha)$ sebesar 5 persen.

\section{Uji Simultan}

Tabel 2 menunjukkan nilai statistik uji pada model pekerja komuter dengan kendaraan bermotor pribadi adalah sebesar 328,125 dan $p$-valuenya sebesar 0,000 . Apabila dibandingkan dengan nilai $\chi_{(4 ; 0,05)}^{2}$ yang sebesar 9,488 maka nilai statistik uji lebih besar dari nilai $\chi_{(4 ; 0,05)}^{2}$. Sehingga keputusan yang dihasilkan adalah tolak $\mathrm{H}_{0}$ dan dapat ditarik kesimpulan bahwa dengan tingkat signifikansi 5 persen, terdapat minimal satu variabel bebas yang berpengaruh signifikan terhadap status stres pekerja komuter yang menggunakan kendaraan bermotor pribadi di Jabodetabek.

Tabel 2. Hasil uji simultan.

\begin{tabular}{ccccc}
\hline Jenis Kendaraan & Step 5 & Chi-Square & df & Sig. \\
\hline \multirow{3}{*}{ Kendaraan Bermotor Pribadi } & Step & $-0,742$ & 1 & 0,389 \\
& Block & 328,125 & 4 & 0,000 \\
& Model & 328,125 & 4 & 0,000 \\
& Step & $-1,035$ & 1 & 0,309 \\
Kendaraan Bermotor Umum & Block & 59,686 & 6 & 0,000 \\
& Model & 59,686 & 6 & 0,000 \\
\hline
\end{tabular}

Sumber: Survei Komuter Jabodetabek 2019 (diolah).

Pada model pekerja komuter dengan kendaraan bermotor umum, didapatkan nilai statistik uji sebesar 59,686 dengan $p$-value sebesar 0,000. Nilai statistik uji tersebut lebih besar dari nilai $\chi_{(6 ; 0,05)}^{2}=12,592$ dan $p$ valuenya kurang dari 0,05 . Dengan begitu dapat disimpulkan bahwa dengan tingkat signifikansi sebesar 5 persen terdapat minimal satu variabel bebas yang memiliki pengaruh signifikan terhadap status stres pekerja komuter dengan kendaraan bermotor umum.

\section{Uji Parsial}

Langkah selanjutnya setelah pengujian simultan adalah melakukan uji parsial. Tabel 3 di bawah ini menunjukkan ringkasan hasil uji parsial pada tahap terakhir untuk model pekerja komuter dengan kendaraan bermotor pribadi dan pekerja komuter dengan kendaraan bermotor umum. Berdasarkan Tabel 3 terdapat tiga 
variabel bebas yang berpengaruh signifikan terhadap status stres pekerja komuter dengan kendaraan bermotor pribadi pada tingkat signifikansi 5 persen yaitu status perkawinan, durasi perjalanan, dan kemacetan. Sedangkan pada pekerja komuter dengan kendaraan bermotor umum, tiga variabel bebas yang memiliki pengaruh signifikan terhadap status stres adalah umur, durasi perjalanan, dan kemacetan. Jenis kelamin, penghasilan per bulan, dan jarak tempuh perjalanan adalah variabel-variabel yang tidak berpengaruh signifikan terhadap status stres pekerja komuter baik pengguna kendaraan bermotor pribadi maupun umum.

Tabel 3. Hasil uji parsial model pekerja komuter dengan kendaraan bermotor pribadi dan umum.

\begin{tabular}{cccccccc}
\hline \multirow{2}{*}{ Variabel } & \multirow{3}{*}{ Dummy } & \multicolumn{3}{c}{$\begin{array}{c}\text { Pekerja Komuter dengan Kendaraan } \\
\text { Bermotor Pribadi }\end{array}$} & \multicolumn{3}{c}{$\begin{array}{c}\text { Pekerja Komuter dengan Kendaraan } \\
\text { Bermotor Umum }\end{array}$} \\
\cline { 3 - 8 } & & $\hat{\beta}$ & Sig. & $\operatorname{Exp}(\hat{\beta})$ & $\hat{\beta}$ & Sig. & $\operatorname{Exp}(\hat{\beta})$ \\
\hline Umur* & & & & & & $\mathbf{0 , 0 0 3}$ & \\
Umur (1)* & $\mathrm{D}_{11}$ & & & & 0,704 & $\mathbf{0 , 0 0 1}$ & 2,022 \\
Umur (2)* & $\mathrm{D}_{12}$ & & & & 0,517 & $\mathbf{0 , 0 1 5}$ & 1,678 \\
Status perkawinan* & $\mathrm{D}_{3}$ & $-0,204$ & $\mathbf{0 , 0 3 0}$ & 0,815 & & & \\
Durasi perjalanan* & & & $\mathbf{0 , 0 0 0}$ & & & $\mathbf{0 , 0 0 2}$ & \\
Durasi perjalanan (1)* & $\mathrm{D}_{51}$ & 0,237 & $\mathbf{0 , 0 1 8}$ & 1,267 & 0,455 & $\mathbf{0 , 0 0 3}$ & 1,576 \\
Durasi perjalanan (2)* & $\mathrm{D}_{52}$ & 0,686 & $\mathbf{0 , 0 0 0}$ & 1,986 & 0,723 & $\mathbf{0 , 0 0 0}$ & 2,061 \\
Kemacetan * & $\mathrm{D}_{7}$ & 1,839 & $\mathbf{0 , 0 0 0}$ & 6,290 & 0,889 & $\mathbf{0 , 0 0 0}$ & 2,433 \\
Constant* & & $-2,304$ & $\mathbf{0 , 0 0 0}$ & 0,100 & $-1,471$ & $\mathbf{0 , 0 0 0}$ & 0,230 \\
\hline
\end{tabular}

*) : variabel signifikan pada alfa $(\alpha)=0,05$

Sumber: Survei Komuter Jabodetabek 2019 (diolah)

Berikut ini adalah model regresi logistik biner yang terbentuk:

- Pekerja komuter dengan kendaraan bermotor pribadi

Setelah dihasilkan nilai penduga parameter $\hat{\beta}$, maka dibentuk persamaan regresi logistik seperti berikut:

$$
\hat{g}(x)=-2,304-0,204 D_{3}{ }^{*}+0,237 D_{51}{ }^{*}+0,686 D_{52}{ }^{*}+1,839 D_{7}{ }^{*}
$$

- Pekerja komuter dengan kendaraan bermotor umum

Persamaan regresi logistik yang terbentuk untuk pekerja komuter yang menggunakan kendaraan bermotor umum adalah sebagai berikut:

$$
\hat{g}(x)=-1,471+0,704 D_{11}{ }^{*}+0,517 D_{12}{ }^{*}+0,455 D_{51}{ }^{*}+0,723 D_{52}{ }^{*}+0,889 D_{7}{ }^{*}
$$

Keterangan:

$\mathrm{D}_{11}$ : variabel dummy umur menengah (31-49 tahun)

$\mathrm{D}_{12}$ : variabel dummy umur muda (15-30 tahun)

$\mathrm{D}_{3}$ : variabel dummy status perkawinan adalah tidak kawin

$\mathrm{D}_{51}$ : variabel dummy durasi perjalanan 31-60 menit

$\mathrm{D}_{52}$ : variabel dummy durasi perjalanan lebih dari 60 menit

$\mathrm{D}_{7}$ : variabel dummy mengalami kemacetan

*) : variabel signifikan pada alfa $(\alpha)=0,05$

\section{Uji Kesesuaian Model}

Hasil uji kesesuaian model disajikan dalam Tabel 4 berikut:

Tabel 4. Hasil uji kesesuaian model.

\begin{tabular}{cccccccc}
\hline \multicolumn{2}{l}{ Pekerja Komuter dengan Kendaraan } & Bermotor Pribadi & \multicolumn{5}{c}{ Pekerja Komuter dengan Kendaraan Bermotor Umum } \\
\hline Step & Chi-Square & df & Sig. & Step & Chi-Square & df & Sig. \\
\hline 5 & 7,957 & 6 & 0,241 & 5 & 5,219 & 8 & 0,734 \\
\hline
\end{tabular}

Sumber: Survei Komuter Jabodetabek 2019 (diolah).

Nilai statistik uji yang diperoleh pada model pekerja komuter dengan kendaraan bermotor pribadi berdasarkan Tabel 4 adalah sebesar 7,957 yang mana lebih kecil dari nilai $\chi_{(6 ; 0,05)}^{2}=12,592$. Kemudian nilai $p$-value yang didapat adalah sebesar 0,241 . Angka tersebut lebih besar dari $\alpha=0,05$. Sehingga $\mathrm{H}_{0}$ gagal ditolak pada tingkat signifikansi 5 persen, yang artinya model regresi logistik biner yang terbentuk telah sesuai untuk menjelaskan status stres pekerja komuter dengan kendaraan bermotor pribadi di Jabodetabek tahun 2019. 
Begitupun dengan model pekerja komuter yang menggunakan kendaraan bermotor umum, di mana nilai statistik uji yang didapatkan adalah sebesar 5,219 dan angka tersebut lebih kecil dari $\chi_{(8 ; 0,05)}^{2}=15,507$. $P$ value diperoleh sebesar 0,734 yang mana lebih besar dari $\alpha=0,05$. Keputusan yang dihasilkan adalah gagal tolak $\mathrm{H}_{0}$. Dapat disimpulkan bahwa model yang terbentuk sudah cocok untuk menjelaskan status stres pada pekerja komuter dengan kendaraan bermotor umum.

\section{Kecenderungan Variabel Bebas yang Berpengaruh Signifikan terhadap Status Stres Pekerja Komuter dengan Kendaraan Bermotor Pribadi dan Umum}

Berikut ini adalah kecenderungan dari variabel bebas yang berpengaruh signifikan terhadap status stres pekerja komuter di dua jenis kendaraan:

\section{Pekerja Komuter dengan Kendaraan Bermotor Pribadi}

- Status Perkawinan

Nilai rasio kecenderungan status perkawinan adalah sebesar 0,815. Angka tersebut menunjukkan bahwa pekerja komuter dengan kendaraan bermotor pribadi yang tidak kawin cenderung lebih tidak stres dibandingkan pekerja komuter yang kawin. Atau dapat juga dikatakan bahwa kecenderungan pekerja komuter yang kawin mengalami stres akibat perjalanan adalah sebesar 1,227 kali dibanding pekerja komuter yang tidak kawin. Hasil ini sejalan dengan penelitian Demiral (2018) yang mendapati bahwa pekerja komuter yang kawin lebih berisiko mengalami stres akibat perjalanan dibanding pekerja komuter yang tidak kawin. Waktu berkomuter yang panjang menyebabkan penurunan waktu luang pekerja komuter dengan pasangan serta anak mereka (Christian, 2012). Hal tersebut menimbulkan tekanan tersendiri bagi pekerja komuter ketika dalam perjalanan dan dapat menyebabkan stres. Selain itu, rasa bebas yang dimiliki pekerja komuter tidak kawin juga dapat menyebabkan rendahnya kecenderungan untuk mengalami stres.

- Durasi Perjalanan

Durasi perjalanan kategori 31-60 menit memiliki rasio kecenderungan sebesar 1,267. Angka tersebut menunjukkan bahwa pekerja komuter yang menggunakan kendaraan bermotor pribadi dengan durasi perjalanan 31-60 menit memiliki kecenderungan untuk mengalami stres perjalanan 1,267 kali lebih besar dibanding yang durasi perjalanannya $\leq 30$ menit. Sedangkan untuk durasi perjalanan $>60$ menit memiliki nilai rasio kecenderungan sebesar 1,986. Dapat dikatakan bahwa pekerja komuter dengan kendaraan bermotor pribadi yang durasi perjalanannya > 60 menit memiliki kecenderungan untuk mengalami stres perjalanan 1,986 kali lebih besar dibanding pekerja komuter yang durasi perjalanannya $\leq 30$ menit. Legrain, Eluru, dan El-Geneidy (2015) juga menemukan bahwa durasi perjalanan pekerja komuter yang menggunakan mobil pribadi memengaruhi status stres secara positif. Artinya semakin lama durasi perjalanan dalam berkomuter maka semakin tinggi tingkat stres yang dirasakan.

- Kemacetan

Rasio kecenderungan kemacetan adalah sebesar 6,290. Dengan nilai rasio kecenderungan tersebut, dapat dikatakan bahwa kecenderungan pekerja komuter dengan kendaraan bermotor pribadi yang mengalami kemacetan untuk merasakan stres perjalanan 6,290 kali lebih besar dibanding pekerja komuter yang tidak mengalami kemacetan. Tingginya kecenderungan merasa stres ketika macet juga sejalan dengan hasil penelitian Haider, Kerr, dan Badami (2013). Fenomena kemacetan menghambat pekerja komuter untuk tiba tepat waktu di tempat kerja sehingga rasa tertekan selama perjalanan tersebut dapat menimbulkan stres (Koslowsky, Kluger, dan Reich, 1995).

\section{Pekerja Komuter dengan Kendaraan Bermotor Umum}

- Umur

Umur (1) memiliki rasio kecenderungan sebesar 2,022. Sehingga dapat dikatakan bahwa pekerja komuter berumur menengah (31-49 tahun) yang menggunakan kendaraan bermotor umum memliki kecenderungan 2,022 kali lebih besar untuk merasa stres akibat perjalanan dibandingkan pekerja komuter berumur tua (50+ tahun). Kemudian, umur (2) memiliki rasio kecenderungan sebesar 1,678. Artinya, pekerja komuter muda (15-30 tahun) memiliki kecenderungan 1,678 kali lebih besar untuk stres dibanding pekerja berumur tua. Haider, Kerr, dan Badami (2013) menyebutkan bahwa peluang pekerja komuter mengalami stres akan terus meningkat hingga kelompok umur 31-49 tahun, lalu menurun pada kelompok umur 50 tahun ke atas. 
- Durasi Perjalanan

Durasi perjalanan (1) memiliki nilai rasio kecenderungan sebesar 1,576. Artinya pekerja komuter yang menggunakan kendaraan bermotor umum dengan durasi perjalanan 31-60 menit memiliki kecenderungan 1,576 kali lebih besar untuk mengalami stres perjalanan dibandingkan pekerja yang durasi perjalanannya $\leq 30$ menit. Selanjutnya, nilai rasio kecenderungan durasi perjalanan (2) adalah sebesar 2,061. Angka tersebut bermakna bahwa kecenderungan pekerja komuter pengguna kendaraan bermotor umum yang menempuh perjalanan $>60$ menit untuk mengalami stres akibat perjalanan 2,061 kali lebih besar dibandingkan pekerja yang menempuh perjalanan $\leq 30$ menit. Cantwell, Caulfield, dan O'Mahony (2009) mengatakan bahwa seiring bertambahnya durasi perjalanan maka tingkat stres pekerja komuter pengguna kendaraan umum akan semakin meningkat.

- Kemacetan

Kemacetan memiliki nilai rasio kecenderungan sebesar 2,433. Dapat dikatakan bahwa kecenderungan pekerja komuter dengan kendaraan bermotor umum dan mengalami kemacetan 2,433 kali lebih besar dibanding pekerja komuter yang tidak mengalami kemacetan. Morris dan Hirsch (2015) menemukan bahwa komuter yang mengalami kemacetan akan memiliki mood negatif dikarenakan tingginya tingkat stres dan rasa lelah yang dialami.

\section{KESIMPULAN}

Berdasarkan hasil penelitian, didapatkan kesimpulan bahwa persentase pekerja komuter dengan kendaraan bermotor pribadi yang mengalami stres akibat perjalanan lebih besar pada pekerja yang berumur tua, berjenis kelamin laki-laki, berstatus kawin, berpendapatan tinggi, menempuh perjalanan dengan durasi perjalanan > 60 menit serta jarak tempuh $>30 \mathrm{~km}$, dan mengalami kemacetan. Sedangkan pada pekerja komuter dengan kendaraan bermotor umum, persentase yang mengalami stres lebih besar pada pekerja yang berumur menengah, berjenis kelamin laki-laki, berstatus kawin, berpendapatan menengah, menempuh perjalanan dengan durasi perjalanan $>60$ menit serta jarak tempuh $>30 \mathrm{~km}$, dan mengalami kemacetan.

Kemudian, proporsi pekerja komuter dengan kendaraan bermotor pribadi yang mengalami stres akibat perjalanan lebih kecil dibandingkan pekerja komuter dengan kendaraan bermotor umum. Dikarenakan adanya perbedaan tersebut maka dibentuklah dua model regresi logistik biner untuk mengetahui variabel yang berpengaruh signifikan terhadap status stres pekerja komuter dengan kendaraan bermotor pribadi dan umum. Pada pekerja komuter dengan kendaraan bermotor pribadi, variabel yang berpengaruh signifikan adalah status perkawinan, durasi perjalanan, dan kemacetan. Sedangkan variabel yang berpengaruh signifikan terhadap status stres pekerja komuter dengan kendaraan bermotor umum adalah umur, durasi perjalanan, dan kemacetan.

Lebih lanjut, untuk pekerja komuter dengan kendaraan bermotor pribadi yang berstatus kawin, menempuh perjalanan dengan waktu 31-60 menit dan atau > 60 menit, serta mengalami kemacetan memiliki kecenderungan yang lebih tinggi untuk merasa stres akibat perjalanan. Sedangkan pekerja komuter dengan kendaraan bermotor umum yang memiliki kecenderungan lebih tinggi untuk merasa stres akibat perjalanan adalah pekerja yang berumur muda dan menengah, durasi perjalanan selama 31-60 menit dan atau > 60 menit, serta mengalami kemacetan.

\section{DAFTAR PUSTAKA}

Aminah S. (2016). Penataan Transportasi Publik-Privat dan Pengembangan Aksesbilitas Masyarakat-Cet. 1. Surabaya: Airlangga University Press.

Anable, J. dan Gatersleben, B. (2005). All Work and No Play? The Role of Instrumental and Affective Factors in Work and Leisure Journeys by Different Travel Modes. Transportation Research Part A, 39, 163-181. BPS. (2019). Analisis Mobilitas Tenaga Kerja. Jakarta: Badan Pusat Statistik.

BPS. (2019). Statistik Komuter Jabodetabek 2019. Jakarta: Badan Pusat Statistik.

BPS. (2020). Statistik Transportasi Darat 2019. Jakarta: Badan Pusat Statistik.

Cantwell, M., Caulfield, B., dan O'Mahony, M. (2009). Examining the Factors that Impact Public Transport Commuting Satisfaction. Journal of Public Transportation, 12(2), 1-21.

Christian, Thomas J. (2012). Automobile Commuting Duration and the Quantity of Time Spent with Spouse, Children, and Friends. Preventive Medicine, 55, 215-218.

Demiral, Ozge. (2018). Commuting Stress- Turnover Intention Relationship and the Mediating Role of Life Satisfaction: An Empirical Analysis of Turkish Employees. Social sciences, 7, 147. 
Haider, M., Kerr, K., dan Badami, M. (2013). Does Commuting Cause Stress? The Public Health Implications of Traffic Congestion. http://dx.doi.org/10.2139/ssrn.2305010

Hosmer, D. W. dan Lemeshow, S. (2013). Applied Logistic Regression (3rd ed.). Canada: John Wiley \& Sons, Inc.

Koslowsky, M., Kluger, A. N., dan Reich, M. (1995). Commuting Stress: Causes, Effects, and Methods Coping. New York: Springer Science+Business Media.

Legrain, A., Eluru, N., dan El-Geneidy, A. (2015). Am stressed, must travel: The relationship between mode choice and commuting stress. Transportation Research Part F: Traffic Psychology and Behaviour, 34, 141-151.

Mao, Z., Ettema, D., dan Dijst, M. (2016). Commuting Trip Satisfaction in Beijing: Exploring the Influence of Multimodal Behavior and Modal Flexibility. Transportation Research Part A, 94, 592-603.

Morris, E. A., \& Hirsch, J. A. (2015). Does Rush Hour See a Rush of Emotions? Driver Mood in Conditions Likely to Exhibit Congestion. Travel Behavior and Society. https://dx.doi.org/10/1016/j.tbs.2015.07.002

O'Regan, B. dan Buckley, F. (2003). The Psychological Effects of Commuting in Dublin. Link working paper series WP 07-04, Dublin City University.

Riyadi, G. A. dan Yudhistira, M. H. (2020). Pola Perilaku Komuter dan Stres: Bukti dari Jabodetabek. Jurnal Ekonomi Kuantitatif Terapan, 13(1), 185-210.

Rosida, I., Sari, D. W., dan Irjayanti, A. D. (2019). The Mode Choices and Commuting Stress: Empirical Evidence from Jakarta and Denpasar. Jurnal Pengembangan Kota, 7(1), 68-76.

Sugianti, I., dan Anggorodi, R. A. (2013). Stres dan Strategi Coping pada Tenaga Kerja Komuter (Penglaju) Pengguna Transportasi Bus TransJakarta. Depok: Universitas Indonesia. http://lib.ui.ac.id/naskahringkas/2015-09/S44373-IRNAMIA\%20SUGIANTI [3 Maret 2021]

Tajalli, M., dan Hajbabaie, A. (2017). On the Relationships Between Commuting Mode Choice and Public Health. Journal of Transport \& Health, 4, 267-277.

Walpole, R. E., Myers, R. H., Myers, S. L., Ye, K. (2011). Probability \& Statistics for Engineers \& Scientists (9th ed.). United States of America: Prentice Hall. 